\title{
PENGARUH KONSENTRASI KATALIS HETEROGEN KALSIUM OKSIDA (CaO) DARI CANGKANG TELUR BEBEK PADA REAKSI TRANSESTERIFIKASI MINYAK KELAPA
}

\author{
Erni Rohmiasih ${ }^{1}$, Sri Rezeki ${ }^{1}$, Syahrul Khairi ${ }^{1}$ \\ ${ }^{1}$ Jurusan Teknik Kimia, Universitas Tanjungpura, Pontianak \\ Email korespondensi : ernirhmi@student.untan.ac.id
}

\begin{abstract}
Abstrak
Eksploitasi bahan bakar fosil yang dilakukan secara terus-menerus menyebabkan jumlahnya semakin menipis. Pemerintah memberikan solusi untuk mengatasi permasalahan tersebut melalui penggunaan bahan bakar alternatif seperti biodiesel. Penggunaan katalis dalam proses produksi biodiesel sangat disarankan. Katalis heterogen berbasis kalsium hasil dekomposisi $\mathrm{CaCO}_{3}$ pada cangkang hewan telah diteliti dapat digunakan sebagai katalis dalam reaksi transesterifikasi. Pada penelitian ini dilakukan dekomposisi $\mathrm{CaCO}_{3}$ menjadi $\mathrm{CaO}$ dari cangkang telur bebek yang dilakukan dengan kalsinasi pada temperatur $900^{\circ} \mathrm{C}$ selama 4 jam. $\mathrm{CaO}$ yang dihasilkan diaplikasikan dalam reaksi transesterifikasi dengan variasi konsentrasi katalis 1, 2, 3 dan 4\%, rasio mol minyak:metanol $1: 9$, temperatur reaksi $63^{\circ} \mathrm{C}$, dan waktu reaksi 3 jam. Berdasarkan difraktogram, kalsinasi cangkang telur bebek pada $900^{\circ} \mathrm{C}$ telah mengkonversi $\mathrm{CaCO}_{3}$ menjadi $\mathrm{CaO}$. Puncak-puncak utama $\mathrm{CaO}$ muncul pada ${ }^{\circ} 2 \theta 32,24 ; 37,41 ; 53,93 ; 64,24 ; 67,47$ dan 91,60 sesuai dengan data standar CaO ICDD No. 01-070-4068. Adapun yield metil ester yang dihasilkan pada setiap konsentrasi katalis yaitu $82,45 \%, 85,93 \%, 93,01 \%$ dan 78,48\%. Metil ester dengan yield tertinggi (katalis 3\%) dianalisis menggunakan GC-MS, berdasarkan analisa GC, terdapat 6 puncak dan berdasarkan spektrum massa teridentifikasi senyawa metil kaprat, metil laurat, metil miristat, metil palmitat, metil oleat dan metil stearat. Metil ester memiliki densitas $860,48 \mathrm{~kg} / \mathrm{m}^{3}$; viskositas $5,8 \mathrm{~mm} / \mathrm{s}$; angka setana 59 ; dan residu karbon $0,34 \%$.
\end{abstract}

10.26418/pipt.2021.22

Kata Kunci : Biodiesel, CaO, GC-MS, Katalis dan Transesterifikasi

\section{PENDAHULUAN}

Indonesia merupakan salah satu negara dengan konsumsi energi terbesar di dunia. Konsumsi energi di Indonesia mengalami peningkatan seiring dengan semakin meningkatnya pertumbuhan ekonomi, perkembangan industri maupun transportasi. Menurut Badan Pengatur Hilir Minyak dan Gas Bumi (BPH Migas), konsumsi energi di Indonesia khususnya pada sektor bahan bakar sepanjang tahun 2018 mencapai 75 juta kl. Hingga saat ini $70 \%$ pemenuhan bahan bakar di Indonesia masih bergantung pada bahan bakar fosil yang jumlahnya semakin berkurang.

Pemerintah telah melakukan upaya dalam mengatasi krisis energi melalui penggunaan bahan bakar alternatif yang ramah lingkungan dan dapat diperbaharui. Salah satu energi alternatif yang dikembangkan yaitu biodiesel. Penggunaan biodiesel telah direalisasikan oleh Pertamina melalui penerapan biosolar atau Fatty Acid Methyl Ester (FAME) yaitu telah mencapai 3,2 juta kl atau 59\% dari alokasi FAME pada periode Januari-Juli 2019.

Biodiesel umumnya diproduksi dari sumber trigliserida berupa minyak nabati seperti minyak kelapa sawit, minyak jarak, minyak kedelai, minyak kelapa dan lain sebagainya. Biodiesel dari minyak kelapa memiliki beberapa kelebihan. Biodiesel dari minyak kelapa memiliki angka setana yang cukup tinggi dibandingkan minyak kelapa sawit dan minyak jarak pagar yaitu 62,7. Semakin tinggi angka setana maka bahan bakar diesel akan semakin mudah terbakar sehingga pembakaran terjadi lebih sempurna dan efisien (Soerawidjaja, 2003).

Selain itu dari segi produktivitas minyak per satuan luas, kelapa sawit lebih unggul 
namun lahan yang sesuai untuk sawit lebih terbatas yaitu hanya di beberapa kawasan, terutama Sumatera dan Kalimantan sedangkan kelapa dapat ditemukan dengan mudah hampir di seluruh wilayah Indonesia. Berdasarkan hal tersebut, penggunaan minyak kelapa sebagai sumber pengembangan energi alternatif dinilai berpotensi terutama untuk daerah- daerah terpencil dengan harga kopra sangat murah, namun harga bahan bakar minyak sangat mahal dan sering tidak tersedia.

Penggunaan minyak nabati secara langsung sebagai bahan bakar diesel menyebabkan perubahan fisik dari komponen-komponen utama motor yang disebabkan oleh kinerja dari komponen tersebut menjadi lebih berat karena minyak nabati memiliki viskositas yang tinggi sehingga jangka waktu perawatan dan penggantian komponen motor bakar diesel menjadi lebih singkat jika dibandingkan dengan penggunaan minyak solar (Reksowardojo, 2004).

Transesterifikasi merupakan salah satu metode yang dapat digunakan untuk menurunkan viskositas minyak nabati. Laju reaksi pada suhu dan tekanan rendah dapat ditingkatkan melalui penggunaan katalis. Katalis yang umumnya digunakan merupakan katalis berfasa homogen. Akan tetapi penggunaan katalis homogen ini memiliki beberapa kekurangan diantaranya sulit untuk dipisahkan dengan produk, sensitif terhadap air dan asam lemak bebas pada minyak, tidak dapat digunakan kembali dan memerlukan treatment khusus agar tidak mencemari lingkungan (Devitria dkk., 2013).

Berdasarkan kelemahan dari katalis homogen yang digunakan dalam pembuatan biodiesel, penggunaan katalis heterogen sangat disarankan. Penggunaan katalis heterogen dalam transesterifikasi dapat mempermudah proses pemisahan produk dengan katalis. Beberapa katalis heterogen telah diteliti dan digunakan sebagai katalis dalam pembuatan biodiesel diantaranya Kalium Nitrat $\left(\mathrm{KNO}_{3}\right)$, Magnesium Oksida $(\mathrm{MgO})$ dan Kalsium Oksida $(\mathrm{CaO})$. Menurut beberapa penelitian yang telah dilakukan, $\mathrm{CaO}$ lebih banyak digunakan karena memiliki kekuatan basa yang relatif tinggi, kelarutan yang rendah dalam metanol, serta bersifat ramah lingkungan.

Beberapa tahun belakangan ini, telah banyak dilakukan penelitian untuk menemukan katalis heterogen dengan memanfaatkan limbah cangkang hewan diantaranya cangkang kerang darah, cangkang kerang batik dan cangkang keong mas. Pada penelitian ini digunakan cangkang telur bebek terkalsinasi sebagai katalis berbasis kalsium. Penggunaan cangkang telur bebek dikarenakan kandungan kalsium karbonat $\left(\mathrm{CaCO}_{3}\right)$ yang tinggi yaitu $96,35 \%$ sehingga berpotensi untuk didekomposisi menjadi $\mathrm{CaO}$ (Tangboriboon, 2012).

Penelitian ini bertujuan untuk mengetahui pengaruh kalsinasi terhadap serbuk cangkang telur bebek, mengetahui pengaruh variasi konsentrasi katalis yang ditambahkan dalam reaksi transesterifikasi, dan mengetahui karakteristik metil ester yang dihasilkan.

\section{METODOLOGI}

Alat - alat yang digunakan pada penelitian ini adalah timbangan analitik, labu leher tiga $500 \mathrm{ml}$, kondensor, termometer, hot plate, magnetic stirer, erlenmeyer $250 \mathrm{ml}$, corong pisah, gelas ukur, statif, penjepit, spatula, buret dan kertas saring.

Adapun bahan-bahan yang digunakan yaitu cangkang telur bebek yang berasal dari peternakan bebek di Dusun Patok Rol Sungai Kakap Kalimantan Barat, minyak kelapa, metanol, akuades, etanol, $\mathrm{NaOH}$ dan indikator phenolphtalein.

\section{Preparasi Katalis}

Sintesis $\mathrm{CaO}$ dari $\mathrm{CaCO}_{3}$ dapat dilakukan melalui penghilangan senyawa organik dan karbon dioksida pada material. Penghilangan senyawa organik pada cangkang telur dapat dilakukan melalui 
kalsinasi pada temperatur di bawah $600^{\circ} \mathrm{C}$, sementara karbon dioksida dapat dilepas pada temperatur $700-800^{\circ} \mathrm{C}$ (Wei, et al., 2009).

Proses preparasi katalis dari cangkang telur bebek dilakukan melalui beberapa tahapan. Tahap pertama cangkang dicuci dengan menggunakan air hingga bersih kemudian dikeringkan di bawah sinar matahari selama 12 jam. Sampel tersebut dikeringkan kembali dengan menggunakan oven selama 10 jam pada temperatur $110^{\circ} \mathrm{C}$. Pengeringan sampel bertujuan untuk mempermudah proses penghalusan cangkang telur bebek. Cangkang telur bebek yang telah kering selanjutnya dihaluskan dan diayak hingga partikel lolos pada saringan 80 mesh. Pengayakan dilakukan untuk menghasilkan serbuk cangkang dengan ukuran yang kecil dan seragam. Tahap kedua serbuk cangkang telur bebek dikalsinasi pada temperatur $900^{\circ} \mathrm{C}$ selama 4 jam. Kalsinasi bertujuan untuk menghilangkan senyawa organik, melepaskan unsur $\mathrm{C}$ dan $\mathrm{O}$ dalam bentuk gas $\mathrm{CO}_{2}$ melalui dekomposisi kalsium karbonat $\left(\mathrm{CaCO}_{3}\right)$ yang terdapat dalam cangkang telur bebek sehingga diperoleh senyawa kalsium oksida $(\mathrm{CaO})$. Cangkang telur bebek yang telah dikalsinasi kemudian didinginkan dalam desikator dan disimpan dalam wadah tertutup. Cangkang telur bebek hasil kalsinasi dikarakterisasi dengan menggunakan XRD.

\section{Reaksi Transesterifikasi menggunakan Katalis $\mathrm{CaO}$}

Reaksi transesterifikasi dilakukan dengan menggunakan variasi konsentrasi katalis $1,2,3$ dan $4 \%$ b/b terhadap berat minyak dengan variabel tetap yaitu perbandingan mol minyak dan metanol 1:9, temperatur reaksi $63^{\circ} \mathrm{C}$ selama 3 jam. Reaksi transesterifikasi dilakukan dengan menggunakan labu leher tiga yang dilengkapi dengan kondensor refluks, termometer dan magnetic stirrer.

Katalis $\mathrm{CaO}$ dari cangkang telur bebek direaksikan dengan metanol selama 1 jam pada temperatur $30^{\circ} \mathrm{C}$. Umumnya alkohol yang sering digunakan merupakan etanol atau metanol. Secara ekonomi, metanol memiliki harga yang lebih murah dari pada etanol, metanol tersedia dalam bentuk absolut yang mudah diperoleh sehingga hidrolisa dan pembentukan sabun akibat air yang terdapat dalam alkohol dapat diminimalkan. Selain itu, metanol memiliki reaktivitas lebih tinggi, hal ini karena metanol merupakan senyawa polar dengan rantai karbon pendek sehingga dapat bereaksi lebih cepat dengan trigliserida dibandingkan alkohol rantai panjang (Sidabutar, 2013).

Setelah katalis direaksikan dengan metanol, minyak kelapa ditambahkan dalam labu leher tiga. Reaksi terjadi selama 180 menit pada suhu reaksi $63^{\circ} \mathrm{C}$. Suhu reaksi dijaga pada temperatur yang telah ditentukan, semakin tinggi suhu reaksi, hasil metil ester yang diperoleh juga semakin besar. Hal ini dikarenakan, reaktan lebih aktif bergerak.

Kemudian campuran didiamkan hingga katalis terendapkan sehingga lebih mudah untuk dipisahkan. Setelah katalis dipisahkan campuran dipindahkan dalam corong pisah dan didiamkan pada temperatur kamar hingga terbentuk dua lapisan. Lapisan bawah adalah gliserol dan lapisan atas adalah metil ester. Metil ester yang terbentuk dipisahkan dan dicuci dengan menggunakan akuades hangat, bertujuan untuk menghilangkan kelebihan metanol dan sisa gliserol. Pencucian dilakukan dengan metode ekstraksi cair-cair menggunakan pelarut akuades yang berdasarkan pada prinsip like disolve like. Sisa metanol dan gliserol akan berinteraksi dengan akuades karena keduanya bersifat polar sedangkan metil ester akan terpisah karena bersifat non polar. Campuran kemudian didiamkan hingga terbentuk dua lapisan. Lapisan bawah merupakan metanol dan sabun yang bercampur dengan air pencuci sedangkan lapisan atas adalah metil ester. Metil ester dipisahkan dan disaring dengan menggunakan kertas saring kemudian dipanaskan untuk menghilangkan air pada metil ester. 
Kemudian dihitung yield yang dihasilkan dari setiap percobaan dengan persamaan berikut (Yin et al., 2016) :

Yield $(\%)=$

$$
\frac{\text { massa yang diperoleh }(\mathrm{g})}{\text { massa teoritis }(\mathrm{g})} \times 100 \%
$$

Metil ester dengan yield maksimum dianalisis dengan menggunakan GC-MS. Gas Chromatography (GC) digunakan untuk mendeteksi jumlah komponen yang terkandung dalam metil ester yang ditunjukkan dalam data berupa kromatogram dengan puncak-puncak tertentu, dilanjutkan dengan analisis dengan Mass Spectroscopy (MS) untuk menentukan berat molekul dan struktur molekul pada tiap puncak fragmentasi dari molekul yang terdeteksi berdasarkan kemiripan dengan senyawa standar.

\section{HASIL DAN PEMBAHASAN}

\section{Preparasi Katalis}

Katalis yang digunakan dalam penelitian ini merupakan kalsium oksida $(\mathrm{CaO})$ yang berasal dari dekomposisi kalsium karbonat $\left(\mathrm{CaCO}_{3}\right)$ yang terdapat pada cangkang telur bebek. Cangkang telur bebek memiliki penampilan fisik berwarna putih hingga putih kehijauan.

Hasil kalsinasi serbuk cangkang telur bebek pada temperatur $900^{\circ} \mathrm{C}$ menunjukan penurunan massa sebesar $50,20 \%$, yang menandakan bahwa $\mathrm{CaCO}_{3}$ telah terdekomposisi. Adapun massa awal serbuk cangkang telur bebek adalah 320 gram dan setelah dikalsinasi diperoleh masa sebesar 159,35 gram. Serbuk cangkang telur bebek yang semula berwarna putih kehijauan mengalami perubahan warna menjadi putih setelah dilakukan kalsinasi. Adapun reaksi yang terjadi yaitu sebagai berikut:

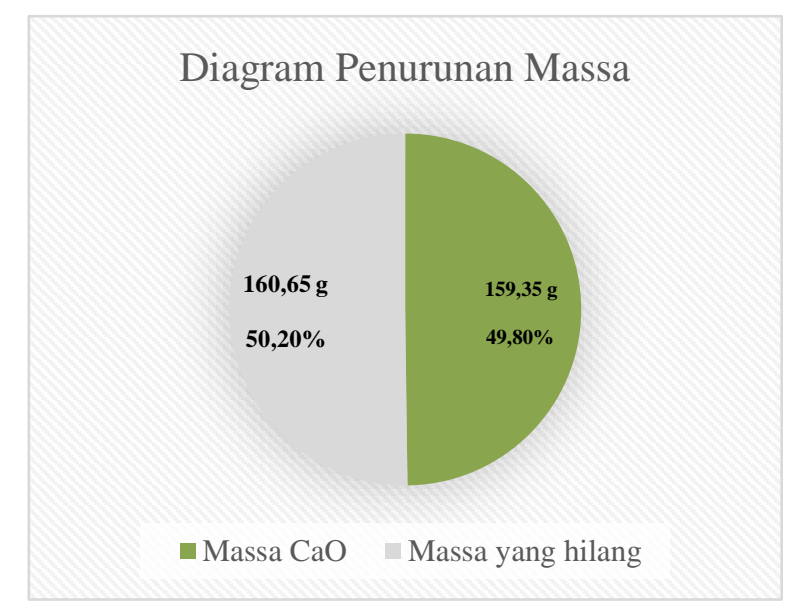

Sumber: (Penulis, 2021)

Gambar 1: Diagram penurunan massa

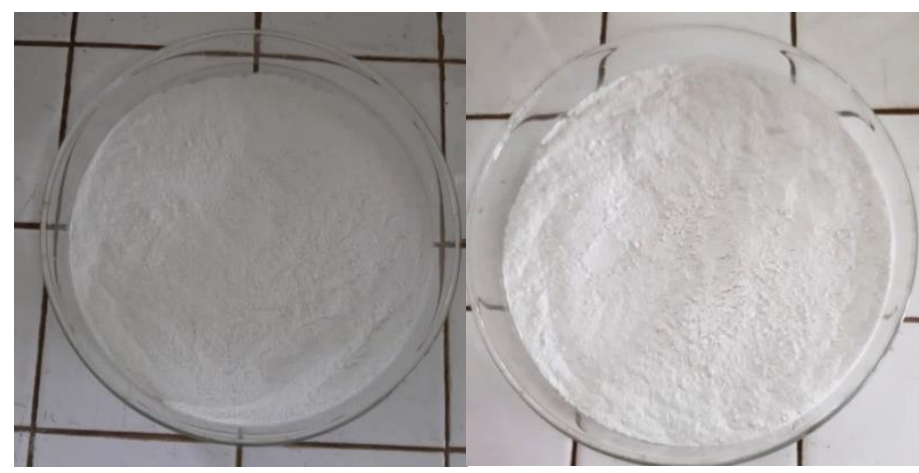

Sumber: (Penulis, 2021)

Gambar 2: Serbuk cangkang telur bebek sebelum kalsinasi (kiri) dan setelah dikalsinasi (kanan) 


\section{Karakterisasi Katalis}

Serbuk cangkang telur bebek hasil kalsinasi dikarakterisasi menggunakan $X$ Ray Diffraction (XRD). Pada penelitian ini juga dilakukan analisis XRD pada serbuk cangkang telur bebek sebelum dikalsinasi sebagai pembanding. Karakterisasi kristal menggunakan XRD bertujuan untuk melihat kristalinitas serta mengetahui komponen pembentuk katalis secara kualitatif melalui puncak- puncak difraksi yang terbentuk sebagai akibat dari pembiasan sinar-X pada sampel kemudian puncak-puncak yang didapatkan dicocokkan dengan standar difraksi sinar-X. Difraktogram yang memiliki pola dengan puncak yang jelas serta intensitas yang tinggi menunjukkan bahwa sampel tersebut memiliki kristalinitas yang baik (Elyana, 2016). Berikut ini merupakan difraktogram serbuk cangkang telur bebek sebelum dan setelah kalsinasi:

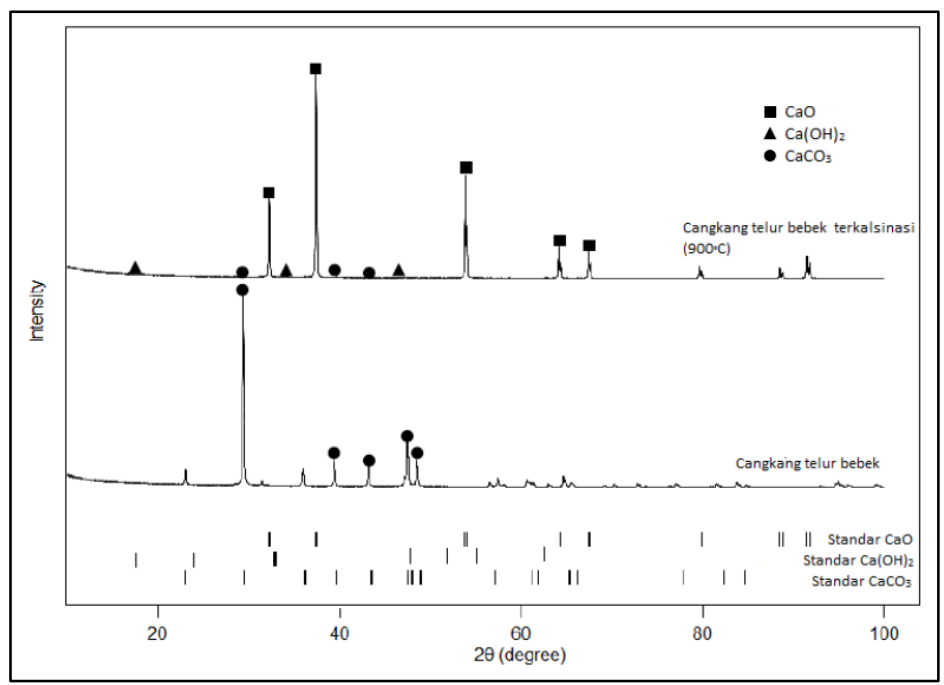

Sumber: (Penulis, 2021)

Gambar 3: Difraktogram serbuk cangkang telur bebek tanpa kalsinasi dan kalsinasi $900^{\circ} \mathrm{C}$

Tabel 1: Komposisi cangkang telur bebek sebelum dan setelah kalsinasi

\begin{tabular}{ccccccc}
\hline \multirow{2}{*}{ Senyawa } & \multicolumn{2}{c}{ ICSD } & \multicolumn{2}{c}{$\begin{array}{c}\text { Cangkang telur } \\
\text { bebek }\end{array}$} & \multicolumn{2}{c}{$\begin{array}{c}\text { Cangkang telur } \\
\text { bebek terkalsinasi } \\
900^{\circ} \mathrm{C}\end{array}$} \\
\cline { 2 - 8 } & $2 \theta\left(^{\circ}\right)$ & $\begin{array}{c}\text { Intensity } \\
(\%)\end{array}$ & $2 \theta\left(^{\circ}\right)$ & $\begin{array}{c}\text { Intensity } \\
(\%)\end{array}$ & $2 \theta\left(^{\circ}\right)$ & $\begin{array}{c}\text { Intensity } \\
(\%)\end{array}$ \\
\hline \multirow{5}{*}{$\mathrm{CaCO}_{3}$} & 29,39 & 100 & 29,38 & 100 & 29,28 & 0,83 \\
& 39,40 & 18,3 & 39,42 & 15,54 & 39,68 & 0,28 \\
& 43,15 & 14,7 & 43,18 & 13,04 & 43,14 & 0,22 \\
& 47,48 & 18,1 & 47,45 & 24,96 & - & - \\
$\mathrm{Ca}(\mathrm{OH})_{2}$ & 38,49 & 19,0 & 48,52 & 17,99 & - & - \\
& 18,11 & 66,3 & - & - & 17,93 & 0,54 \\
& 28,73 & 18,4 & - & - & - & - \\
& 47,25 & 100 & - & - & 33,99 & 0,73 \\
$\mathrm{CaO}$ & 50,89 & 26,9 & - & - & 47,27 & 0,29 \\
& 32,22 & 41,6 & - & - & 32,24 & 38,77 \\
& 37,38 & 100 & - & - & 37,41 & 100 \\
& 53,90 & 49,8 & - & - & 53,93 & 63,92 \\
\hline
\end{tabular}




\begin{tabular}{llllll}
\hline 64,20 & 12,4 & - & - & 64,24 & 15,83 \\
67,43 & 12,5 & - & - & 67,47 & 15,52 \\
\hline
\end{tabular}

Sumber: (Penulis, 2021)

Berdasarkan difraktogram (Gambar 3) cangkang telur bebek sebelum dan setelah kalsinasi memperlihatkan peak yang berbeda, hal ini menunjukkan bahwa cangkang telur bebek sebelum dikalsinasi memiliki struktur kristal yang berbeda dengan cangkang telur bebek setelah dikalsinasi. Pada difraktogram cangkang telur bebek sebelum kalsinasi menampilkan puncak- puncak karakteristik $\mathrm{CaCO}_{3}$ yang dikonfirmasi sesuai dengan data standar ICDD (International Centre for Diffraction Data ) No. 01-078-4614.

Berdasarkan difraktogram cangkang telur bebek sebelum kalsinasi tidak terdapat $\mathrm{CaO}$, hal ini karena sebagian besar komponen penyusun cangkang telur bebek adalah $\mathrm{CaCO}_{3}$. Puncak- puncak karakteristik $\mathrm{CaCO}_{3}$ pada cangkang telur bebek muncul pada puncak utama ${ }^{\circ} 2 \theta 29,38 ; 39,42 ; 43,18$; 47,45 dan 48,52. Sedangkan pada difraktogram sampel cangkang telur bebek yang dikalsinasi pada $900^{\circ} \mathrm{C}$, terlihat karakteristik $\mathrm{CaO}$ yang muncul pada puncak yang sesuai dengan data standar CaO ICDD No. 01-070-4068. Sebagian besar partikel $\mathrm{CaCO}_{3}$ telah terdekomposisi menjadi $\mathrm{CaO}$, namun masih terdapat $\mathrm{CaCO}_{3}$ dan terbentuk $\mathrm{Ca}(\mathrm{OH})_{2}$ dengan intensitas yang kecil. Pada cangkang telur bebek yang dikalsinasi pada $900^{\circ} \mathrm{C}$, sebagian besar puncak-puncak yang muncul menggambarkan karakteristik $\mathrm{CaO}$ yaitu pada ${ }^{\circ} 2 \theta 32,24 ; 37,41 ; 53,93 ; 64,24$; 67,47 dan sebagian kecil $\mathrm{CaCO}_{3}$ belum terkonversi yang teridentifikasi dalam puncak yang muncul pada ${ }^{\circ} 2 \theta 29,28 ; 39,68$, 43,14 serta terbentuk senyawa $\mathrm{Ca}(\mathrm{OH})_{2}$ dalam jumlah kecil yang teridentifikasi pada puncak yang muncul pada ${ }^{\circ} 2 \theta 17,93 ; 33,99$ dan 47,27.

Pola XRD menunjukkan puncakpuncak yang sempit dan tajam mengilustrasikan kristalinitas yang tinggi. Perbedaan difraktogram cangkang telur bebek sebelum dan setelah kalsinasi menunjukkan bahwa cangkang telur bebek sebelum dan setelah kalsinasi memiliki struktur kristal yang berbeda. Kalsinasi pada temperatur $900^{\circ} \mathrm{C}$ selama 4 jam telah mendekomposisi $\mathrm{CaCO} 3$ pada cangkang telur bebek menjadi $\mathrm{CaO}$ akibat dari evolusi $\mathrm{CO} 2$ dari $\mathrm{CaCO} 3$ pada temperatur tinggi.

\section{Penentuan Ukuran Kristal}

Ukuran kristal cangkang telur bebek sebelum dan setelah dikalsinasi ditentukan melalui pendekatan Debye Scherrer. Data yang digunakan terdiri dari nilai panjang gelombang, intensitas, $2 \theta$ dan FWHM yang dihasilkan dari hasil uji XRD. Banyaknya puncak yang terbentuk menunjukan bahwa kristal yang terbentuk merupakan polikristalin. Tiap puncak menunjukkan ukuran butir kristal sehingga akan diperoleh beberapa ukuran kristal dan diambil rataratanya. Kurva suatu puncak difraksi akan melebar terutama untuk ukuran kristal kurang dari $100 \mathrm{~nm}$. Berdasarkan persamaan, nilai ukuran kristal yang dihasilkan akan berbanding terbalik dengan FWHM, sedangkan nilai FWHM dipengaruhi oleh intensitas masing- masing bidang kristal, dimana semakin tinggi intensitas maka nilai FWHM semakin kecil. Ukuran kristal dapat dihitung dengan menggunakan persamaan scherrer yang ditunjukkan pada persamaan berikut: (Didik, 2020).

$\tau=\frac{K \lambda}{\beta \cos \theta}$

Berdasarkan hasil perhitungan dengan menggunakan persamaan scherrer cangkang telur bebek sebelum dan setelah dikalsinasi, diperoleh ukuran kristal rata-rata serbuk cangkang telur bebek yaitu 24,69 nm sedangkan untuk ukuran kristal serbuk cangkang telur bebek yang dikalsinasi yaitu $22,82 \mathrm{~nm}$. 


\section{Reaksi Transesterifikasi}

Reaksi transesterifikasi dilakukan dengan menggunakan sistem refluks untuk mencegah metanol menguap ke lingkungan. Pada proses transesterifikasi, $\mathrm{CaO}$ direaksikan dengan metanol. Reaksi antara $\mathrm{CaO}$ dan metanol bertujuan untuk membentuk ion metoksida yang akan berinteraksi dengan trigliserida.

Mekanisme reaksi transesterifikasi yang terjadi dengan menggunakan katalis $\mathrm{CaO}$ terjadi dalam 4 tahap. Pada tahap 1 terjadi reaksi antara metanol $\left(\mathrm{CH}_{3} \mathrm{OH}\right)$ dengan kalsium oksida $(\mathrm{CaO})$. Senyawa $\mathrm{CaO}$ merupakan basa lewis yang mempunyai pasangan elektron valensi menyendiri (bebas) yang dapat didonorkan pada atom yang memiliki kekurangan elektron atau disebut asam lewis. Elektron valensi bebas pada $\mathrm{CaO}$ didonorkan pada $\mathrm{H}^{+}$yang merupakan asam lewis menghasilkan senyawa metoksida yang memiliki muatan negatif (anion metoksida) dan katalis terprotonasi. Anion metoksida merupakan nukleofil yang secara selektif dapat berikatan atau menyerang muatan positif dari sebuah gugus kimia.

Pada tahap 2 gugus karbonil trigliserida $(\mathrm{C}=\mathrm{O})$ diserang oleh anion metoksida, sehingga mengakibatkan terputusnya ikatan $\pi$ pada $\mathrm{C}=\mathrm{O}$ sehingga muatan atom $-\mathrm{O}$ menjadi negatif. Penyerangan ini menghasilkan senyawa antara berbentuk tetrahedral.

Pada tahap 3 pasangan elektron bebas dari $\mathrm{O}^{-}$membentuk rangkap kembali dengan karbonil $(\mathrm{C}=\mathrm{O})$ menyebabkan terlepasnya $\mathrm{C}-\mathrm{O}$ sehingga senyawa antara yang berbentuk tertrahedral mengalami penataan ulang, menghasilkan metil ester dan ion digliserida.

Pada tahap 4, ion digliserida bereaksi dengan katalis terprotonasi. Pasangan elektron bebas pada $\mathrm{O}^{-}$mendonorkan elektron pada $\mathrm{H}^{+}$sehingga menghasilkan digliserida dan regenerasi katalis. Selanjutnya anion metoksida menyerang gugus karbonil lain dalam digliserida hingga membentuk satu mol metil ester dan monogliserida. Langkah ini terus berlanjut hingga reaksi mencapai kesetimbangan.

\section{Pengaruh Variasi Konsentrasi Katalis}

Transesterifikasi minyak kelapa dengan katalis $\mathrm{CaO}$ dilakukan pada konsentrasi katalis 1, 2, 3, dan $4 \%$ b/b. Variasi konsentrasi katalis dilakukan untuk menentukan konsentrasi katalis optimum pada reaksi transesterifikasi.

Berdasarkan hasil penelitian yang dilakukan menunjukkan bahwa jumlah katalis akan mempengaruhi yield metil ester yang dihasilkan. Penambahan jumlah katalis akan meningkatkan jumlah molekul yang teraktifkan yang menyebabkan kecepatan reaksi meningkat sehingga yield yang dihasilkan bertambah seiring dengan bertambahnya jumlah katalis. Pada penambahan katalis sebanyak 1, 2 dan 3\% terbentuk 2 lapisan bening. Sedangkan pada penggunaan katalis $4 \%$ terbentuk 3 lapisan, terdapat lapisan berwarna putih pada tengah lapisan yang diperkirakan sabun akibat dari reaksi antara trigliserida dan $\mathrm{CaO}$ berlebih, sehingga menyebabkan yield metil ester menurun. Hal ini diperkirakan karena konsentrasi katalis telah melampaui kondisi optimum.

Penggunaan katalis berlebih dapat menyebabkan terbentuknya emulsi akibat dari reaksi penyabunan sehingga yield yang dihasilkan menurun (Ristianingsih, 2015). Adapun yield metil ester yang dihasilkan pada penggunaan katalis 1, 2, 3 dan $4 \%$ yaitu sebesar 82,45\%, 85,93\%, 93,01\% dan $78,48 \%$.

\section{Analisis Metil Ester}

Analisis metil ester dengan metode GCMS dilakukan terhadap metil ester hasil reaksi transeterifikasi dengan yield tertinggi (konsentrasi $\mathrm{CaO}$ 3\%).

Berdasarkan hasil analisis, reaksi transesterifikasi minyak kelapa dan metanol dengan katalis $\mathrm{CaO}$ dari cangkang telur bebek berhasil mengkonversi minyak kelapa menjadi metil ester. Berikut ini merupakan perbandingan kromatogram metil ester dari 
minyak kelapa pada penelitian ini dan kromatogram hasil penelitian Prayanto (2016).

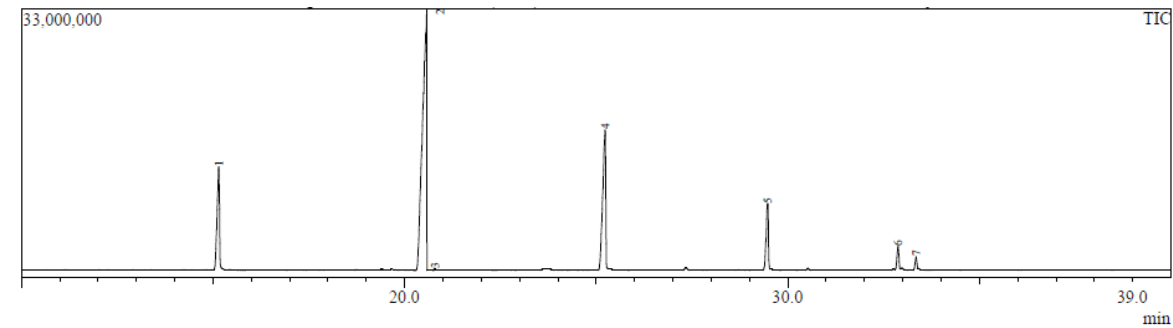

Sumber: (Penulis, 2021)

Gambar 4: Kromatogram metil ester dari minyak kelapa dengan menggunakan katalis $\mathrm{CaO}$ dari cangkang telur bebek

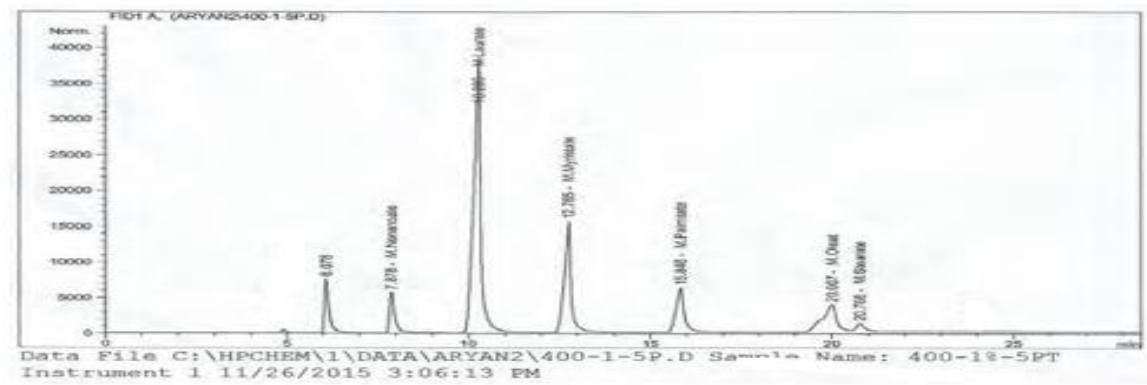

Sumber: (Prayanto, 2016)

Gambar 5: Kromatogram metil ester dari minyak kelapa

Berdasarkan kromatogram metil ester hasil penelitian ini (Gambar 4) teridentifikasi 6 puncak dengan waktu retensi antara 15,14 - 33,35 menit. Puncak dengan intensitas tertinggi berada pada puncak kedua. Adapun komponen yang paling tinggi adalah metil laurat yaitu puncak no. 2 dengan waktu retensi 20,57 menit dan area 55,39\%, hal ini dikarenakan komponen utama asam lemak dalam minyak kelapa merupakan asam laurat. Adapun komponen lain yang terdapat dalam metil ester secara berurutan berdasarkan luas area tertinggi ke terendah yaitu metil miristat pada waktu retensi 25,23 menit dengan area $21,40 \%$, metil kaprat pada waktu retensi 15,14 menit dengan area $12,22 \%$, metil palmitat pada waktu retensi 29,47 menit dengan area $7,66 \%$, metil octadekanoat pada waktu retensi 32,88 menit dengan area $2,19 \%$, dan metil stearat pada waktu retensi 33,35 menit dengan area $1,07 \%$. Hasil ini sesuai dengan penelitian sebelumnya yang dilakukan oleh Prayanto (2016) dimana kromatogram metil ester dari minyak kelapa memiliki puncak tertinggi yang teridentifikasi sebagai metil laurat .

Tabel 2: Komponen senyawa metil ester

\begin{tabular}{ccccc}
\hline Peak & R. Time & Area $(\%)$ & Formula & Nama Senyawa \\
\hline 1 & 15,14 & 12,22 & $\mathrm{C}_{11} \mathrm{H}_{22} \mathrm{O}_{2}$ & Methyl Caprate \\
2 & 20,57 & 55,39 & $\mathrm{C}_{13} \mathrm{H}_{26} \mathrm{O}_{2}$ & Methyl Laurate \\
3 & 25,23 & 21,40 & $\mathrm{C}_{15} \mathrm{H}_{30} \mathrm{O}_{2}$ & Methyl Myristate \\
4 & 29,47 & 7,66 & $\mathrm{C}_{17} \mathrm{H}_{34} \mathrm{O}_{2}$ & Methyl Palmitate \\
5 & 32,88 & 2,19 & $\mathrm{C}_{19} \mathrm{H}_{36} \mathrm{O}_{2}$ & Methyl Oleat \\
6 & 33,35 & 1,07 & $\mathrm{C}_{19} \mathrm{H}_{38} \mathrm{O}_{2}$ & Methyl Stearate \\
\hline
\end{tabular}

Sumber: (Penulis, 2021) 
Spektrum massa senyawa pada puncak 1 dengan waktu retensi (Rt) 15,148 menit memberikan puncak dengan $\mathrm{m} / \mathrm{z}$ 41, 59, 74, 87, 101, 115, 129, 143, 155, dan 186. Berdasarkan pendekatan dengan literatur, spektrum massa senyawa pada puncak 1 memiliki pola fragmentasi yang mirip dengan senyawa decanoic methyl ester (metil kaprat) dengan formula $\mathrm{C}_{11} \mathrm{H}_{22} \mathrm{O}_{2}$. Spektrum massa untuk senyawa pada $\mathrm{Rt}$ 15,148 menit dan spektrum standar metil kaprat dapat dilihat pada Gambar 6.

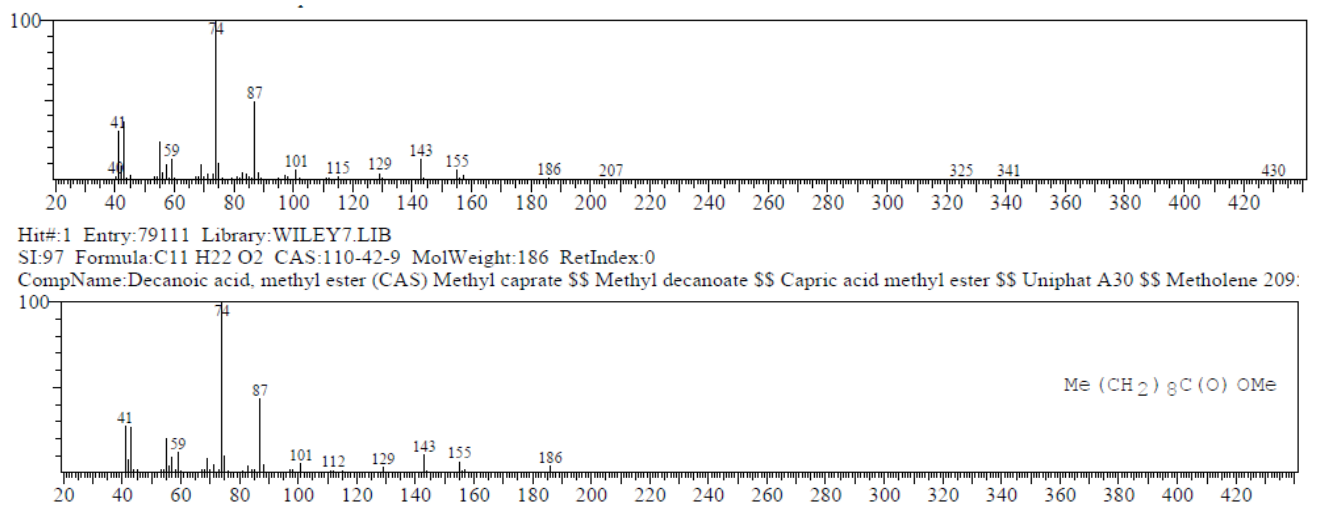

Sumber: (Penulis, 2021)

Gambar 6: Spektrum massa senyawa pada puncak 1 dan standar wiley7.lib (Rt. 15.148)

Berdasarkan spektrum massa, puncak dasar muncul pada $\mathrm{m} / \mathrm{z} 74$ berasal dari $\mathrm{C}_{3} \mathrm{H}_{6} \mathrm{O}_{2}$ yang terbentuk karena pemecahan $\beta$ melalui penataan ulang Mc. Lafferty. Keberadaan ion Mc. Lafferty menegaskan bahwa senyawa yang terdeteksi merupakan metil ester. Pemecahan m/z 155 berasal ion molekul $\mathrm{C}_{10} \mathrm{H}_{19} \mathrm{O}^{+}$yang dihasilkan dari pelepasan ion metoksi dari puncak ion molekul m/z 186. Pecahan m/z 143, 129, 115, 101 dan 87 berasal dari pemecahan deret ion dengan pola $\mathrm{C}_{\mathrm{n}} \mathrm{H}_{2 \mathrm{n}-1} \mathrm{O}_{2}{ }^{+}$, untuk $\mathrm{m} / \mathrm{z}$ 143 berasal dari $\mathrm{C}_{8} \mathrm{H}_{15} \mathrm{O}_{2}$ akibat pelepasan gugus $\mathrm{C}_{3} \mathrm{H}_{7}$ sedangkan yang lainnya berasal dari pelepasan gugus $\mathrm{CH}_{2}$.
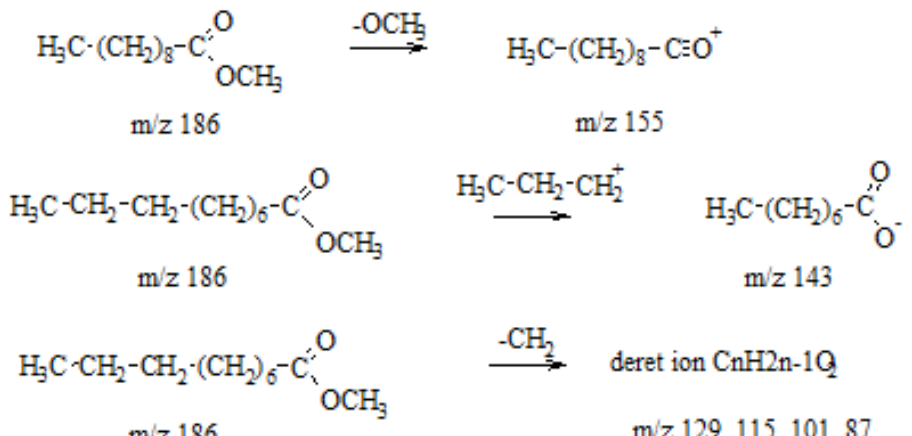
$\mathrm{m} / \mathrm{z} 129,115,101,87$

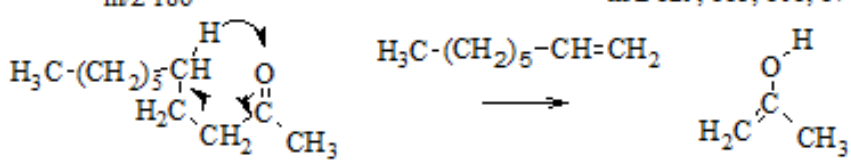

Sumber: (Penulis, 2021)

Gambar 7: Perkiraan mekanisme pola fragmentasi senyawa metil kaprat

Spektrum massa senyawa pada puncak 2 dengan waktu retensi 20,571 menit memberikan massa/muatan $\mathrm{m} / \mathrm{z}$ 40, 41, 57,
74, 87, 101, 115, 129, 143, 157, 171, 183, 199 dan 214. Spektrum massa senyawa pada puncak 2 identik dengan spektrum massa 
dodecanoic methyl ester (metil laurat) dengan formula $\mathrm{C}_{13} \mathrm{H}_{26} \mathrm{O}_{2}$. Spektrum massa untuk senyawa pada Rt 20,571 menit dan spektrum standar metil laurat dapat dilihat pada Gambar 8.
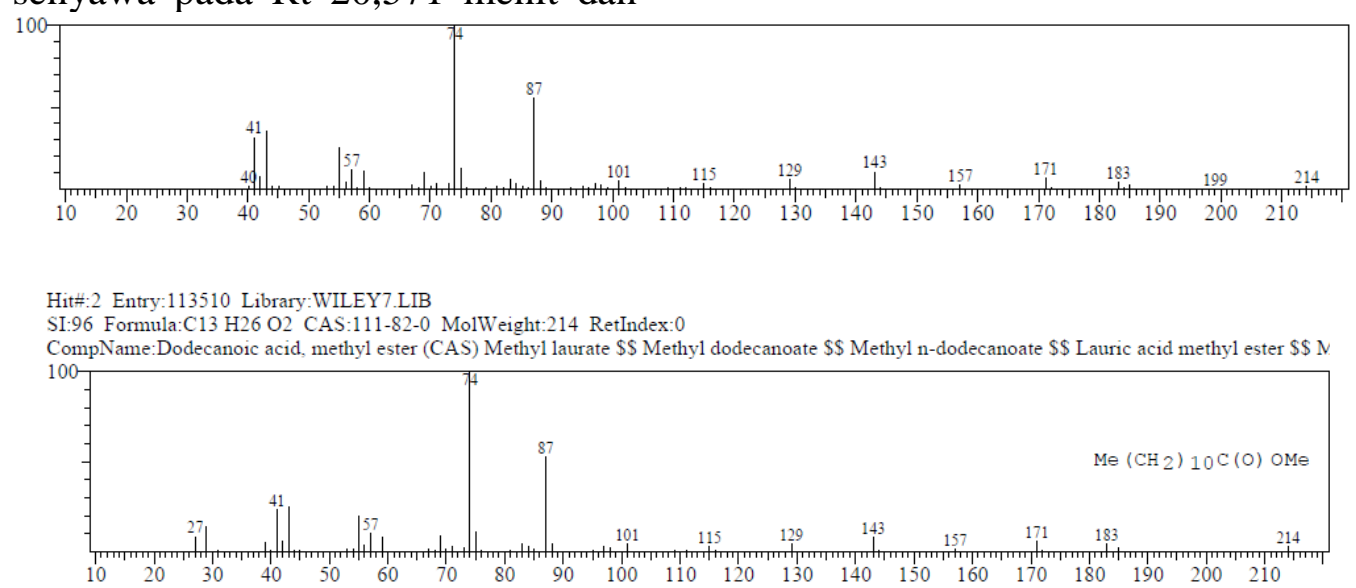

Sumber: (Penulis, 2021)

Gambar 8: Spektrum massa senyawa pada puncak 2 dan standar wiley7.lib (rt 20.167)

Berdasarkan gambar, terlihat bahwa ion molekul muncul pada puncak m/z 214 menggambarkan berat molekul metil laurat yaitu 214. Pemecahan m/z 199 dihasilkan dari pemecahan molekul $\mathrm{CH}_{3}$. Pemecahan $\mathrm{m} / \mathrm{z} 183$ berasal dari $\mathrm{C}_{12} \mathrm{H}_{23} \mathrm{O}^{+}$yang dihasilkan dari pelepasan gugus metoksi ($\mathrm{OCH}_{3}$ ) dari peak ion molekul. Puncak dasar muncul pada m/z 74 berasal dari $\mathrm{C}_{3} \mathrm{H}_{6} \mathrm{O}_{2}$ yang terbentuk karena pemecahan $\beta$ melalui penataan ulang $M c$. Lafferty. Sedangkan pada pemecahan $\mathrm{m} / \mathrm{z} 171,157,143,129$, 115, 101 dan 87 merupakan pola pemecahan deret ion $\mathrm{C}_{\mathrm{n}} \mathrm{H}_{2 \mathrm{n}-1} \mathrm{O}_{2}{ }^{+}$, untuk $\mathrm{m} / \mathrm{z} 171$ berasal dari pelepasan gugus propil dari puncak ion molekul 214 dan yang lainnya berasal dari pelepasan gugus $\mathrm{CH}_{2}$.

$$
\begin{aligned}
& \mathrm{H}_{3} \mathrm{C}-\left(\mathrm{CH}_{2}\right)_{10}-\mathrm{C}^{2} \mathrm{OCH}_{3} \\
& \stackrel{-\mathrm{CH}_{3}}{\longrightarrow} \quad \mathrm{H}_{3} \mathrm{C}-\left(\mathrm{CH}_{2}\right)_{10}-\mathrm{C}^{\prime \prime} \mathrm{O} \\
& \mathrm{m} / \mathrm{z} 214 \\
& \text { m/z } 199 \\
& \mathrm{H}_{3} \mathrm{C}-\left(\mathrm{CH}_{2}\right)_{10}-\mathrm{C}^{\prime \prime} \mathrm{OCH}_{3} \\
& \stackrel{-\mathrm{OCH}_{3}}{\longrightarrow} \quad \mathrm{H}_{3} \mathrm{C}-\left(\mathrm{CH}_{2}\right)_{10}-\mathrm{C} \equiv \mathrm{O}^{+} \\
& \mathrm{m} / \mathrm{z} 214 \\
& \mathrm{~m} / \mathrm{z} 183 \\
& \mathrm{H}_{3} \mathrm{C}-\mathrm{CH}_{2}-\left(\mathrm{CH}_{2}\right)_{9}-\mathrm{C}^{\prime \prime} \mathrm{OCH}_{3} \stackrel{-\mathrm{CH}_{2}}{\longrightarrow} \\
& \text { deret ion } \mathrm{CnH} 2 \mathrm{n}-1 \mathrm{O}_{2} \\
& \mathrm{~m} / \mathrm{z}^{214}
\end{aligned}
$$

Spektrum massa senyawa pada puncak 3 dengan waktu retensi 25,234 menit memberikan $\mathrm{m} / \mathrm{z}$ 40, 41, 57, 74, 87, 101, $115,129,143,157,171,185,199,211$ dan 242. Spektrum massa senyawa pada puncak 3 identik dengan spektrum massa tetradecanoic methyl ester (metil miristat) dengan formula $\mathrm{C}_{15} \mathrm{H}_{30} \mathrm{O}_{2}$. Spektrum massa untuk senyawa pada Rt 25,234 menit dan spektrum standar metil miristat dapat dilihat pada Gambar 10. 


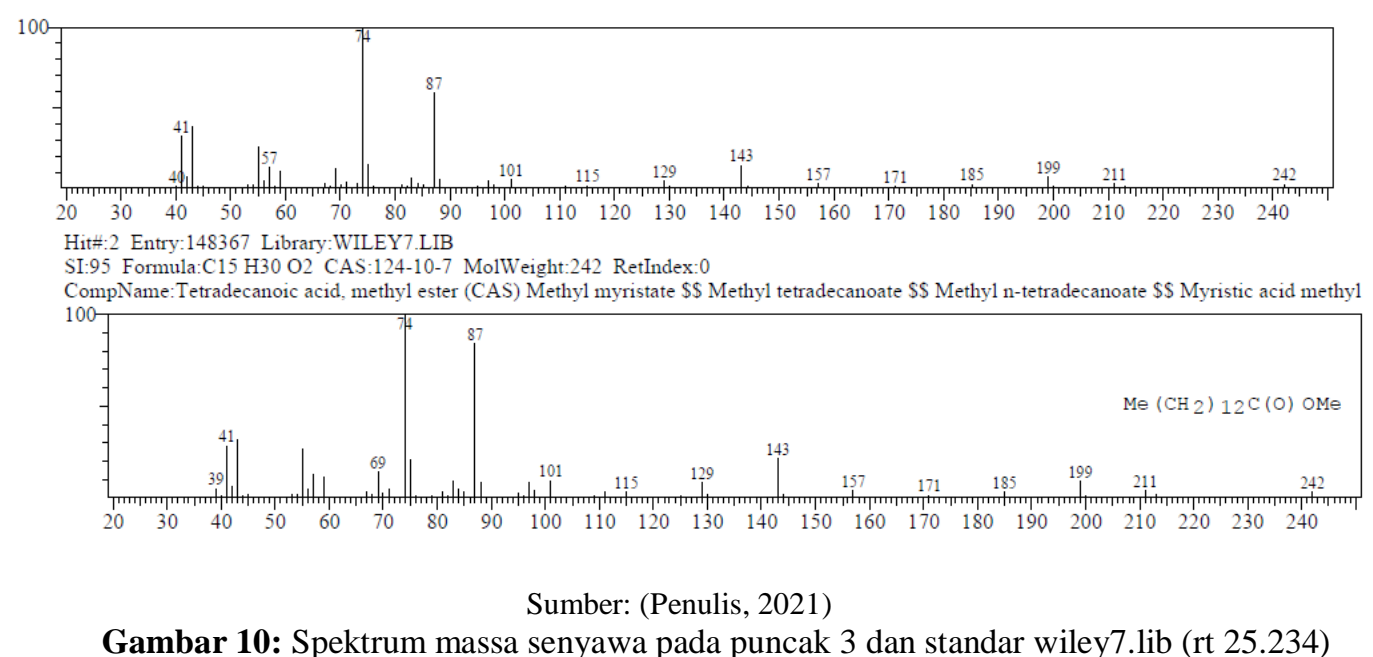

Pola fragmentasi tersebut hampir serupa dengan pola fragmentasi pada senyawa metil laurat, hanya saja pada metil miristat memiliki rantai lebih panjang, dimana senyawa miristat memiliki 2 jumlah atom karbon lebih banyak dibandingkan metil laurat. Berdasarkan gambar, terlihat bahwa ion molekul muncul pada puncak dengan $\mathrm{m} / \mathrm{z}=242$ menggambarkan berat molekul metil miristat yaitu 242. Pada spektrum metil miristat juga muncul puncak dasar pada pemecahan $\mathrm{m} / \mathrm{z}$ 74. Pemecahan $\mathrm{m} / \mathrm{z} 211$ diperoleh dari pelepasan gugus metoksi ($\mathrm{OCH}_{3}$ ) dari ion molekul. Puncak dengan $\mathrm{m} / \mathrm{z}$ 199, 185, 171, 157, 143, 129, 115, 101, dan 87 merupakan pola fragmentasi deret ion $\mathrm{C}_{\mathrm{n}} \mathrm{H}_{2 \mathrm{n}-1} \mathrm{O}_{2}{ }^{+}$, untuk puncak m/z 199 diperoleh dari pelepasan gugus $\mathrm{C}_{3} \mathrm{H}_{7}$, sedangkan yang lainnya berasal dari pelepasan gugus $\mathrm{CH}_{2}$.

$$
\begin{aligned}
& \mathrm{H}_{3} \mathrm{C}-\mathrm{CH}_{2}-\mathrm{CH}_{2}-\left(\mathrm{CH}_{2}\right)_{8}-\mathrm{C}^{\prime \prime} \mathrm{OCH}_{3} \stackrel{-\mathrm{OCH}_{3}}{\longrightarrow} \quad \mathrm{H}_{3} \mathrm{C}-\mathrm{CH}_{2}-\mathrm{CH}_{2}-\left(\mathrm{CH}_{2}\right)_{8}-\mathrm{C} \equiv \mathrm{O}^{+} \\
& \mathrm{m} / \mathrm{z} 242 \mathrm{~m} / \mathrm{z} 21
\end{aligned}
$$

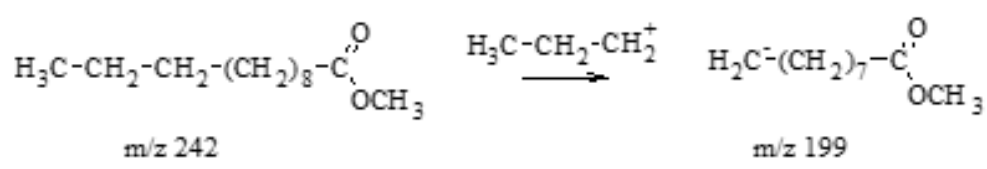

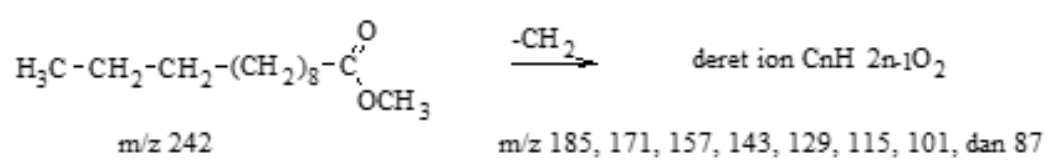

Sumber: (Penulis, 2021)

Gambar 11: Perkiraan mekanisme pola fragmentasi senyawa metil miristat

Spektrum massa senyawa pada puncak 4 dengan waktu retensi 29,475 menit diduga merupakan senyawa hexadecanoic methyl ester (metil palmitat). Spektrum massa tersebut memberikan massa/muatan $\mathrm{m} / \mathrm{z} 40$,
$41,57,74,87,101,115,129,143,157,171$, 185, 199, 213, 227, 239 dan 270. Spektrum massa untuk senyawa pada Rt 29,475 menit dan spektrum massa standar metil palmitat dapat dilihat pada Gambar 12.

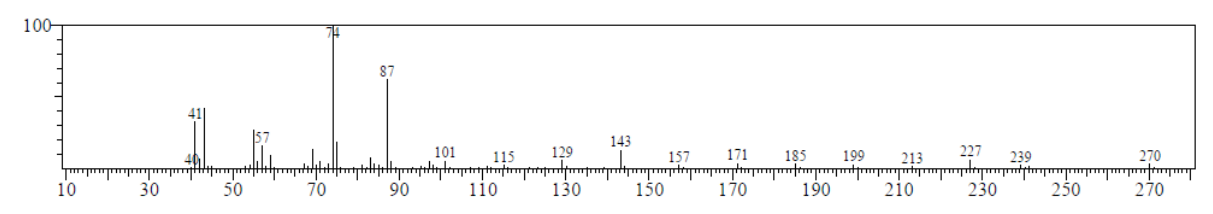




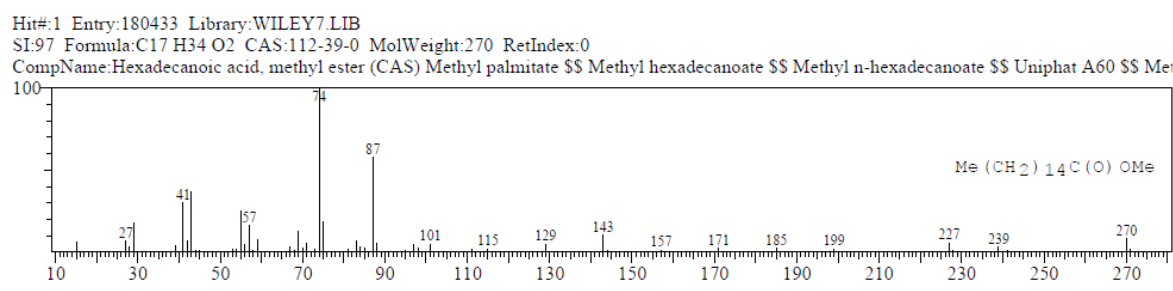

Sumber: (Penulis, 2021)

Gambar 12: Spektrum massa senyawa pada puncak 4 dan standar wiley7.lib (rt 29.475)

Ion molekul mucul pada puncak $\mathrm{m} / \mathrm{z}$ 270 sebagai berat molekul metil palmitat $\left(\mathrm{C}_{17} \mathrm{H}_{34} \mathrm{O}_{2}\right)$. Puncak m/z 239 berasal dari $\mathrm{C}_{16} \mathrm{H}_{31} \mathrm{O}^{+}$yang dihasilkan dari pelepasan gugus metoksi dari puncak ion molekul. Puncak dengan m/z 227, 213, 199, 185, 171, 157, 143, 129, 115, 101, dan 87 merupakan pola fragmentasi deret ion $\mathrm{C}_{\mathrm{n}} \mathrm{H}_{2 \mathrm{n}-1} \mathrm{O}_{2}{ }^{+}$ berasal dari pelepasan gugus $\mathrm{CH}_{2}$. Puncak dasar muncul pada $\mathrm{m} / \mathrm{z} 74$ melalui penataan ulang Mc. Lafferty.

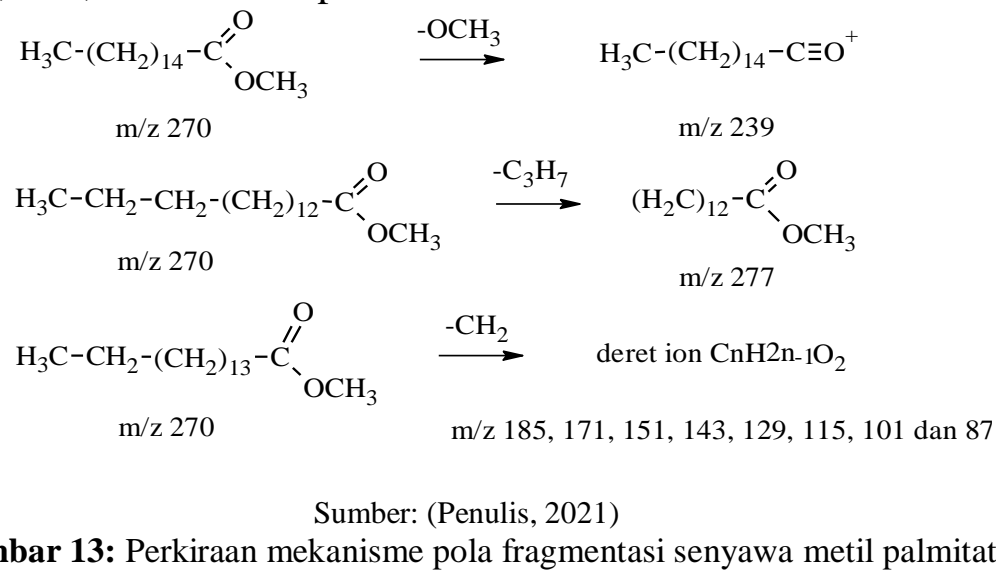

Gambar 13: Perkiraan mekanisme pola fragmentasi senyawa metil palmitat

Spektrum massa pada puncak 5 dengan waktu retensi 32,880 menit diduga merupakan senyawa metil oleat. Spektrum massa senyawa pada rt 32,880 menit dan spektrum massa standar metil oleat dapat dilihat pada Gambar 14.

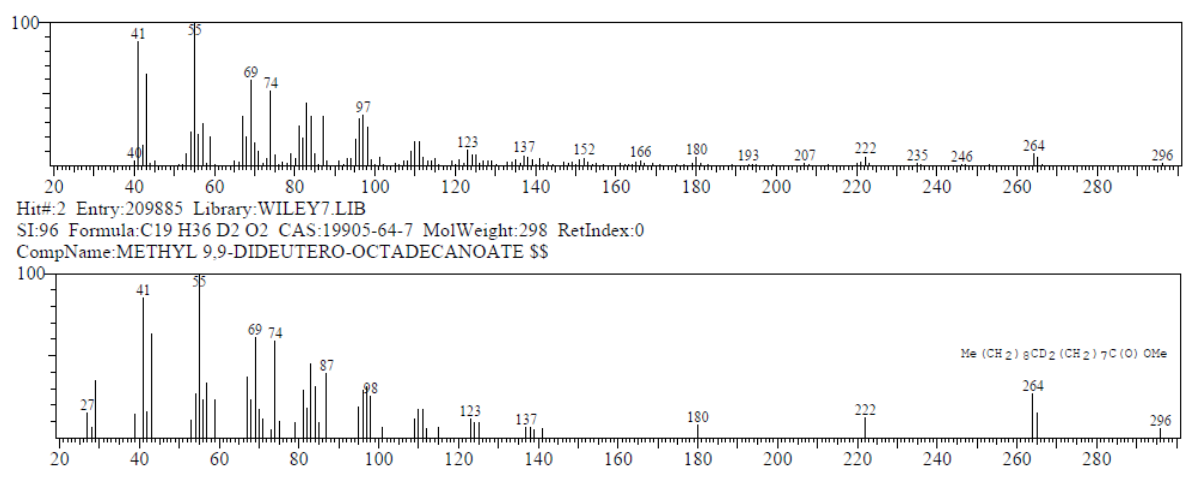

Sumber: (Penulis, 2021)

Gambar 14: Spektrum massa senyawa pada puncak 5 dan standar wiley7.lib (rt 32.880)

Puncak ion molekul muncul pada $\mathrm{m} / \mathrm{z}$ 296 yang menggambarkan berat molekul metil oleat. Berbeda dari senyawa pada puncak sebelumnya, spektrum pada puncak
6 tidak memiliki puncak dasar $\mathrm{m} / \mathrm{z} 74$ melainkan $\mathrm{m} / \mathrm{z}$ 55. Pemecahan $\mathrm{m} / \mathrm{z} 264$ berasal dari pelepasan $\mathrm{CH} 3-\mathrm{OH}$ pada senyawa ion molekul. Fragmen dengan $\mathrm{m} / \mathrm{z}$ 
222 berasal dari pelepasan gugus $\mathrm{C} 3 \mathrm{H} 6$ pada fragmen $\mathrm{m} / \mathrm{z} 264$, fragmen dengan $\mathrm{m} / \mathrm{z} 180$ berasal dari pelepasan $\mathrm{C} 3 \mathrm{H} 6$ dari fragmen $\mathrm{m} / \mathrm{z}$ 222. Selanjutnya, fragmen $\mathrm{m} / \mathrm{z} 166$ berasal dari pelepasan $\mathrm{CH} 2$ dari fragmen $\mathrm{m} / \mathrm{z}$ 180. Fragmen $\mathrm{m} / \mathrm{z} 137$ berasal dari pelepasan $\mathrm{C} 2 \mathrm{H} 5$ dari fragmen $\mathrm{m} / \mathrm{z} 166$. Fragmen m/z 123 berasal dari pelepasan $\mathrm{CH} 2$ pada fragmen $\mathrm{m} / \mathrm{z} 137$. Fragmen $\mathrm{m} / \mathrm{z}$ 97 berasal dari pelepasan $(\mathrm{CH} 2) 2$ dari fragmen $\mathrm{m} / \mathrm{z}$ 123. Fragmen $\mathrm{m} / \mathrm{z} 55$ berasal dari C3H6 dari fragmen 97.

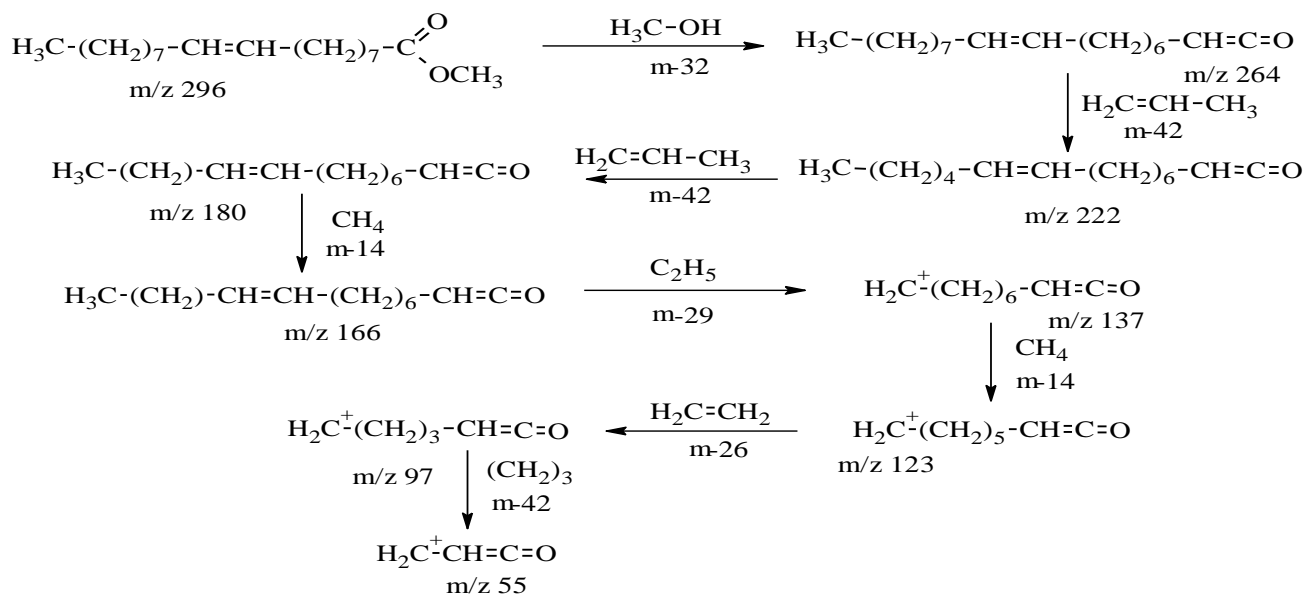

Sumber: (Penulis, 2021)

Gambar 15: Perkiraan mekanisme pola fragmentasi senyawa metil oleat

Spektrum massa pada puncak 6 dengan waktu retensi 33,350 menit diduga merupakan seyawa octadecanoic methyl

ester (metil stearat). Spektrum massa pada Rt 33,350 menit dan spektrum massa standar dapat dilihat pada Gambar 16.

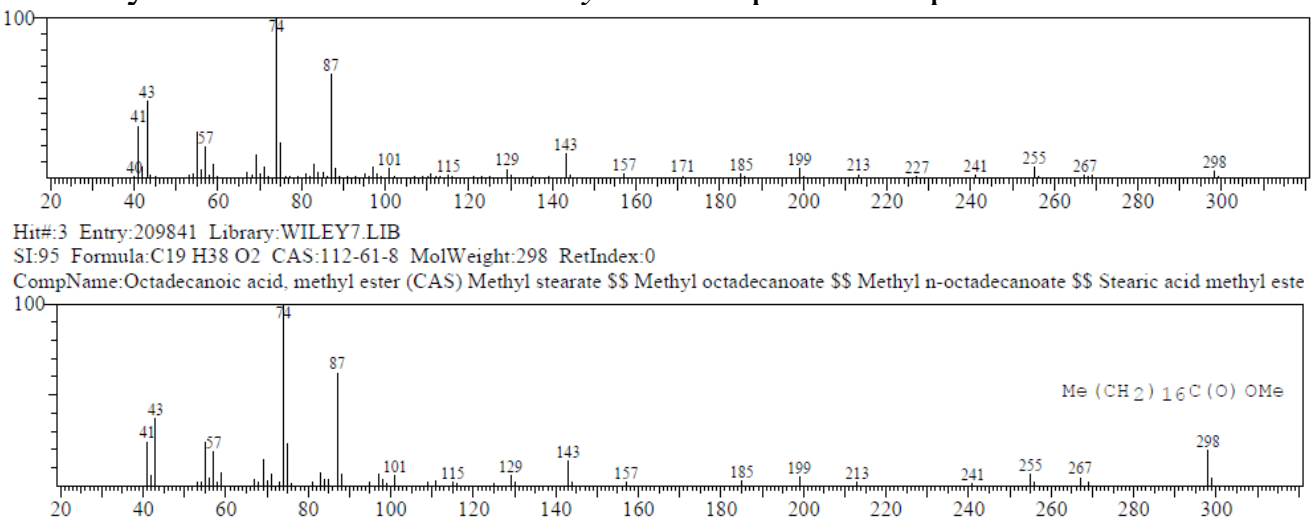

Sumber: (Penulis, 2021)

Gambar 16: Spektrum massa senyawa pada puncak 6 dan standar wiley7.lib (rt 33.350)

Spektrum massa tersebut memberikan massa/muatan $\mathrm{m} / \mathrm{z} 40,41,43,57,74,87$, $101,115,129,143,157,171,185,199,213$, 227, 241, 255, 267 dan 298. Puncak dasar muncul pada $\mathrm{m} / \mathrm{z} 74$ berasal dari $\mathrm{C}_{3} \mathrm{H}_{6} \mathrm{O}_{2}$ yang terbentuk karena pemecahan $\beta$ melalui penataan ulang $M c$. Lafferty. Puncak $\mathrm{m} / \mathrm{z}$ 267 berasal dari pelepasan ion metoksi pada ion molekul, puncak m/z 255 berasal dari pelepasan $\mathrm{C}_{3} \mathrm{H}_{7}$. Sementara pecahan dengan $\mathrm{m} / \mathrm{z} 87,101,115,129,143,157,171,185$, 199, 213, 227, dan 241 dihasilkan dari lepasnya gugus $\mathrm{CH}_{2}$ dengan pola fragmentasi deret ion $\mathrm{C}_{\mathrm{n}} \mathrm{H}_{2 \mathrm{n}-1} \mathrm{O}_{2}{ }^{+}$ 


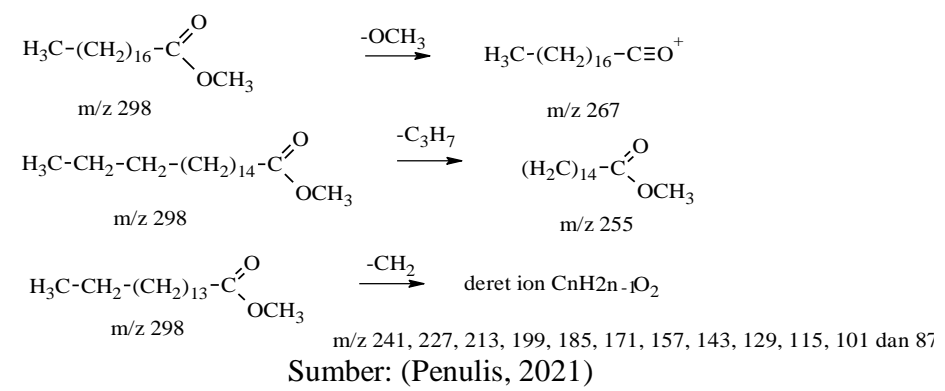

Gambar 17: Perkiraan mekanisme pola fragmentasi senyawa metil ester stearat

\section{Karakteristik Metil Ester}

Metil ester dengan yield maksimum dianalisis untuk mengetahui kualitas metil ester yang dihasilkan sebagai bahan bakar biodiesel. Hasil karakteristik metil ester yang diperoleh ditampilkan dalam Tabel 3 dan dibandingkan dengan karakteristik biodiesel menurut Standar Nasional Indonesia (SNI) 7182: 2015.

Tabel 3 : Karakteristik Metil Ester

\begin{tabular}{|c|c|c|}
\hline Parameter & Hasil & SNI \\
\hline Densitas & $\begin{array}{l}860,48 \\
\left(\mathrm{~kg} / \mathrm{m}^{3}\right)\end{array}$ & $\begin{array}{l}850-890 \\
\left(\mathrm{~kg} / \mathrm{m}^{3}\right)\end{array}$ \\
\hline Viskositas & $\begin{array}{c}5,8 \\
\left(\mathrm{~mm}^{2} / \mathrm{s}\right)\end{array}$ & $\begin{array}{l}2,3-6,0 \\
\left(\mathrm{~mm}^{2} / \mathrm{s}\right)\end{array}$ \\
\hline $\begin{array}{l}\text { Cetane } \\
\text { number }\end{array}$ & 59,0 & $\operatorname{Min} 51$ \\
\hline Residu karbon & $0,34 \%$ & $0,3 \%$ \\
\hline
\end{tabular}

Sumber: (Penulis, 2021)

\section{a. Densitas}

Densitas yang diperoleh pada sampel adalah 860,48 $\mathrm{kg} / \mathrm{m}^{3}$. Hasil tersebut memenuhi standar yang telah ditetapkan oleh SNI 7182: 2015, dimana densitas metil ester yang diperbolehkan berkisar antara $850-890 \mathrm{~kg} / \mathrm{m}^{3}$.

b. Viskositas

Berdasarkan hasil penelitian, diperoleh nilai viskositas kinematik sebesar $5,8 \mathrm{~mm}^{2} / \mathrm{s}$. Viskositas metil ester yang diperoleh lebih rendah daripada viskositas minyak kelapa. Hal ini bersesuai dengan penelitian Hamid (2002), dimana proses transesterifikasi minyak nabati dapat menurunkan viskositasnya. Penurunan viskositas tersebut disebabkan oleh pemutusan gugus gliserol dari minyak kelapa. Viskositas yang diperoleh telah sesuai dengan SNI biodiesel 7182:2015, dimana standar viskositas kinematika berada dalam rentang 2,3-6,0 $\mathrm{mm}^{2} / \mathrm{s}$.

\section{c. Cetane number}

Cetane number metil ester yang diperoleh telah memenuhi SNI biodiesel yaitu bernilai 59,0. Menurut SNI biodiesel 7182: 2015, standar cetane number pada biodiesel bernilai minimal 51 .

d. Residu karbon

Residu karbon yang terdapat pada biodiesel dalam skala besar dapat membentuk endapan yang dapat menyebabakan timbulnya penyumbatan pada injektor. Hasil analisis menyatakan residu karbon pada sampel metil ester bernilai $0,34 \%$ yang melebihi standar SNI yaitu $0,3 \%$.

\section{KESIMPULAN}

Berdasarkan penelitian yang telah dilakukan dapat disimpulkan bahwa:

1. Kalsinasi cangkang telur bebek pada temperatur $900^{\circ} \mathrm{C}$ selama 4 jam mengakibatkan struktur kristal pada cangkang tersebut berubah. Perubahan struktur kristal diakibatkan oleh dekomposisi $\mathrm{CaCO}_{3}$ pada cangkang telur bebek menjadi $\mathrm{CaO}$. Puncak-puncak utama $\mathrm{CaO}$ muncul pada ${ }^{\circ} 2 \theta$ 32,24; 37,$41 ; 53,93 ; 64,24 ; 67,47$ dan 91,60 sesuai dengan data standar $\mathrm{CaO}$ ICDD No. 01-070-4068.

2. Konsentrasi katalis yang digunakan mempengaruhi yield yang dihasilkan pada reaksi transesterifikasi. Semakin 
banyak katalis yang digunakan semakin banyak yield yang dihasilkan. Adapun yield yang diperoleh pada penambahan katalis sebanyak 1, 2, 3 dan 4\% yaitu sebesar 82,45\%, 85,93\%, 93,01\% dan $78,48 \%$. Kondisi optimum diperoleh pada penggunaan katalis 3\% dengan yield sebesar $93,01 \%$.

3. Berdasarkan kromatogram metil ester, terdapat 6 puncak yang muncul yaitu pada waktu retensi 15,$14 ; 20,57 ; 25,23$; 29,48; 32,88 dan 33,35 menit. Adapun senyawa penyusun metil ester tersebut yaitu metil kaprat, metil laurat, metil miristat, metil palmitat, metil oleat dan metil stearat. Sebagian besar senyawa yang terdapat dalam metil ester berupa metil laurat.

4. Metil ester maksimum yang dihasilkan dengan menggunakan katalis optimum (3\%), memiliki karakteristik densitas $860,48 \mathrm{~kg} / \mathrm{m}^{3}$, viskositas $5,8 \mathrm{~mm}^{2} / \mathrm{s}$, angka setana 59 dan residu karbon 0,34\%. Paramater densitas, viskositas dan angka setana telah memenuhi SNI biodiesel 7182: 2015 sedangkan residu karbon melampaui standar.

\section{DAFTAR PUSTAKA}

Devitria, R.; Nurhayati, dan Sofia Anita. (2013). Sintesis Biodiesel dengan Katalis Heterogen Lempung Cengar yang Diaktivasi dengan $\mathrm{NaOH}$ : Pengaruh Waktu Reaksi dan Rasio Molar Minyak : Metanol. J. Ind. Che. Acta. Vol. 3 (2). ISSN 2085-0050

Didik, L. A., (2020). Penentuan Ukuran Butir Kristal $\mathrm{CuCr}_{0,98} \mathrm{Ni}_{0,02} \mathrm{O}_{2}$ dengan Menggunakan X-Ray Difraction (XRD) dan Scanning Electron Microscope (SEM). Indonesia Physical Review 3 (1)

Ketaren. (2005). Pengantar Teknologi Minyak dan Lemak Pangan. Jakarta :Universitas Indonesia Press.

Kirk, R. E. and D. F. Othmer. (1980). Encyclopedia of Chemical
Technology. New York. Wiley \& Sons, Inc. 9,291-298

Ristianingsih, Y., Nurul Hi., dan Fradita Wanda Sari. (2015). Pembuatan Biodiesel dari Crude Palm Oil (CPO) sebagai Bahan Bakar Alternatif melalui Proses Transesterifikasi Langsung. Jurnal Teknologi Agro-Industri. Vol.2 (1)

Roeksowardojo, I. K., Haryanto., Brodjonegoro, T. P., Soerawidjaja, T.H., Dewi, R. G., Syaharuddin, I., Arismunandar, W. (2004). The effect of Biodiesel Fuel from Refined Bleach Deodorized Palm Oil (RBDPO) on an Indirect Injection (IDI) Diesel Engine.The International Workshop on Biomass \& Clean Fossil Fuel Power Plant Technology, Jakarta. Indonesia

Sidabutar, E. D. C.; M. Nur Faniudin, dan M. Said. (2013). Pengaruh Rasio Reaktan dan Jumlah Katalis terhadap Konversi Minyak Jagung menjadi Metil Ester. Jurnal Teknik Kimia 19 (1)

Soerawidjaja dan Tatang Hernas. (2003). Standar Tentatif Biodiesel Indonesia dan Metode-Metode Pengujian. Bandung: Forum Biodiesel Indonesia

Tangboriboon, N.; R. Kunanuruksapong, and A. Sirivat. (2012). Preparation and Properties of Calcium Oxide from Eggshells via Calcination. Materials Science-Poland 30

Wei, Z., Xu C., \& Liu B. (2009). Application of Waste Eggshell as Low-Cost Solid Base Catalyst for Biodiesel Production. Journal Bioresouce Technology 100: 6362-6368

Yin, X.; Xiuli Duan; Qinghong You; Chunhua Dai; Zhongbiao Tan and Xiaoyan Zhu. (2016). Biodiesel Production from Soybean Oil Deodorizer Distillate Using Calcined 
Bidang Lingkungan Binaan dan Rekayasa

Eggshell as Catalyst. Energy

Conversion and Management 112.

Hlm.199-207 